\title{
Teori Belajar Humanistik dan Implikasinya dalam Mata Pelajaran Pendidikan Agama Islam
}

\author{
Fikri Armedyatama \\ Jurusan Ilmu Agama Islam, Fakultas Ilmu Sosial, Universitas Negeri Padang, Indonesia \\ fikri.tama1515@gmail.com
}

\begin{abstract}
This study aims to describe humanistic learning theory and its implications for the learning of Islamic Education. This research method uses library research or library research to be analyzed and concluded. Research data is obtained from recording books and journals. The results of this study contain an understanding of humanistic learning, humanistic learning figures listed: 1) Abraham Maslow as follows; a) Abraham Maslow's biography,b) Abraham Maslow's humanistic learning theory c) Implications of Abraham Maslow's Theory in Islamic Education. 2) Carl Rogers's humanistic learning theory and the implications of Carl Rogers's theory in learning Islamic Education. Conclusion of humanistic theories to humanize humans. the learning process is considered successful if the student discusses his environment and claims himself. Students in the learning process must try to make it more slowly and able to achieve self-actualization as well as possible.
\end{abstract}

Keywords: Learning theory, Humanistic, PAI

\section{Pendahuluan}

Pendidikan dan pengajaran adalah salah satu upaya mencapai target atau tujuan yang secara runtut mengarah pada perbaikan tingkah laku menuju kedewasaan anak didik. Perubahan-perubahan itu menunjukkan tahap-tahap yang harus dilewati. Tanpa proses itu tujuan tidak dapat tercapai, proses yang dimaksud adalahproses pendidikan dan pengajaran. Pengajaran adalah proses dengan fungsi menuntun peserta didik dalam menjalani kehidupan, yaitu menuntun serta memaksimalkan potensi diri sesuai dengan amanat perkembangan yang harus dilalui para peserta didik. Tugas-tugas perkembangan tersebut meliputi kebutuhan bertahan hidup sebagai individu maupun sebagai makhluk sosial serta sebagai makhluk yang diciptakan Tuhan.

Pendidikan merupakan rangkaian humanisasi berasal dari pemikiran faham humanistik. Hal tersebut relevan dengan arti fundamental paham humanistik sebagai pengedukasian manusia. Sistem edukasi Islam yang disusun di atas fondasi nilai-nilai kemanusiaan sedariawal kelahirannya sejalan dengan esensi Islam sebagai agama yang humanistik. Islam memposisikan aspek kemanusiaan sebagai arah pendidikannya. Edukasi dan proses pembelajaran di bangku sekolah dipandang kurang demokratis. Minimnya wadah bagi siswa dan siswi untuk mengembangkan daya imajinasi dan kreasi dengan sudut pandang mereka. Padahal, daya kreasi dan kompetensi kritis dalam berpikir adalah modal berharga bagi anak supaya dapat mengatasi tantangan dan lebih kompetitif. 
Jurnal Pendidikan Agama Islam

ISSN: 1829-5746 | EISSN: 2502-2075

Vol. (Angka Romawi), No. (Angka), (BulanTahun)

An-Nuha: Jurnal Pendidikan Agama Islam | page12 


\section{Tinjauan Pustaka}

Tujuan belajar menurut Teori Humanistik adalah untuk memanusiakan manusia. Proses belajar dianggap berhasil jika si pelajar memahami lingkungannya dan dirinya sendiri. Siswa dalam proses belajarnya harus berusaha agar lambatlaun ia mampu mencapai aktualisasi diri dengan sebaik-baiknya.Dalam teori belajar ini proses belajar harus berhubungan dengan manusia. Meskipun teori ini sangat mementingkan isi dan proses dari belajarnya, tetapi pada dasarnya teori ini lebih cenderung ke pendidikan dan proses belajar dalam bentuk yang paling ideal.

Tokoh-tokoh dari aliran ini adalah Abraham Maslow. Maslow terkenal sebagai bapak aliran psikologi humanistic, ia yakin bahwa manusia berperilaku guna mengenal dan mengapresiasi dirinya sebaik-baiknya. Teori yang termasyhur hingga saat ini yaitu teori hirarki kebutuhan. Menurutnya manusia terdorong guna mencukupi kebutuhannya. Kebutuhan-kebutuhan itu mempunyai level dari yang paling dasar hingga level tertinggi. Dalam teori psikologinya yaitu semakin besar kebutuhan maka pencapaian yang dipunyai oleh individu semakin sungguh-sungguh menggeluti sesuatu.

\section{MetodePenelitian}

Jenis penelitian yang digunakan merupakan jenis penelitian menggunakan data kualitatif dan penelitian ini dilakukan menggunakan jenis penelitian untuk menguraikan hasil kajian rumusan masalah untuk diuraikan secara rinci.

Penelitian kualitatif dilaksanakan untuk membangun pengetahuan melalui pemahaman dan penemuan. Pendekatan penelitian kualitatif adalah suatu proses penelitian dan pemahaman yang berdasarkan pada metode yang menyelidiki suatu fenomena social dan masalah manusia. Pada penelitian ini peneliti membuat suatu gambaran kompleks, meneliti kata-kata, laporan terinci dari pandagan responden dan melakukan studi pada situasi yang alami.

\section{Hasil dan Pembahasan}

Secara luas definisi teori belajar humanisitk ialah sebagai aktivitas jasmani dan rohani guna memaksimalkan proses perkembangan. Sedangkan secara sempit pembelajaran diartikan sebagai upaya menguasai khazanah ilmu pengetahuan sebagai rangkaian pembentukan kepribadian secara menyeluruh. Pertumbuhan yang bersifat jasmaniah tidak memberikan perkembangan tingkah laku. Perubahan atau perkembangan hanya disebabkan oleh proses pembelajaran seperti perubahan habit atau kebiasaan, berbagai kemampuan dalam hal pengetahuan, sikap maupun keterampilan.

Pandangan dalam teori humanisme, manusia memegang kendali terhadap kehidupan dan perilaku mereka, serta berhak untuk mengembangkan sikap dan kepribadian mereka. Masih dalam pandangan humanism bahwa belajar bertujuan untuk menjadikan manusia selayaknya manusia, keberhasilan belajar ditandai bila peserta didik mengenali dirinya dan lingkungan sekitarnya dengan baik. Peserta didik dihadapkan pada target untuk mencapai tingkat aktualisasi diri semaksimal mungkin. Teori humanistic berupaya mengerti tingkah laku belajar menurut pandangan peserta didik dan bukan dari pandangan pengamat.

Humanisme meyakini pusat belajar ada pada peserta didik dan pendidik berperan hanya sebagai fasilitator. Sikap serta pengetahuan merupakan syarat untuk mencapai tujuan pengaktualisasian diri dalam lingkungan yang mendukung. Manusia pada 
dasarnya adalah makhluk yang spesial, mereka mempunyai potensi dan motivasi dalam pengembangan diri maupun perilaku, oleh karenanya setiap individu adalah merdeka dalam upaya pengembangan diri serta pengaktualisasiannya.

Penerapan teori humanistic pada kegiatan belajar hendaknya pendidik menuntun peserta didik berpikir induktif, mengutamakan praktik serta menekankan pentingnya partisipasi pesertadidik dalam pembelajaran. Hal tersebut dapat diaplikasikan dengan diskusi sehingga peserta didik mampu mengungkapkan pemikiran mereka di hadapan audience. Pendidik mempersilakan peserta didik menanyakan materi pelajaran yang kurang dimengerti. Proses belajar menurut pandangan humanistik bersifat pengembangan kepribadian, kerohanian, perkembangan tingkah laku serta mampu memahami fenomena di masyarakat. Tanda kesuksesan penerapan tersebut yaitu peserta didik merasa nyaman dan bersemangat dalam proses pembelajaran serta adanya perubahan positif cara berpikir, tingkah laku serta pengendalian diri.

Bagi penganut teori humanistik, rangkaian pembelajaran berangkat dan kembali kepada individu. Dari teori-teori belajar behavioristik, kognitif dan kunstruktivistik, teori inilah yang paling abstrak, yang mendekati dunia filsafat. Realitasnya pandangan ini membahas pembelajaran dan segala aspeknya dalam kemasan paling ideal. Artinya pandangan ini menaruh minat pada pemikiran pembelajaran yang paling ideal dan relevan dari pada pembelajaran pada umumnya.

Tokoh teori belajar humanistik di antaranya yaitu Abraham Maslow. Menurutnya perspektif humanistik (humanistic perspective) menuntut potensi peserta didik dalam proses tumbuh kembang, kebebasan menemukan jalan hidup. Humanistik menganggap peserta didik sebagai subjek yang merdeka guna menetapkan tujuan hidup dirinya. Peserta didik dituntun agar memiliki sifat tanggung jawab terhadap kehidupannya dan orang di sekitarnya.

Pembelajaran humanistik menaruh perhatian bahwa pembelajaran yang pokok yaitu upaya membangun komunikasi dan hubungan individu dengan individu maupun individu dengan kelompok. Edukasi bukan semata-mata memindah khazanah pengetahuan dan menempa kecakapan berbahasa para peserta didik, tapi sebagai wujud pertolongan supaya siswa mampu mengaktualisasikan dirinya relevan dengan tujuan pendidikan. Edukasi yang berhasil pada intinya adalah kecakapan menghadirkan makna antara pendidik dengan pembelajar sehingga dapat mencapai tujuan menjadi manusia yang unggul dan bijaksana. Maksudnya yaitu menuntun peserta didik bahwa mereka butuh pendidikan karakter. Pendidik memfasilitasi siswa menggali, mengembangkan dan menerapkan kecakapan-kecakapan yang mereka punya supaya mampu memaksimalkan potensinya.

Maslow terkenal sebagai bapak aliran psikologi humanistic, ia yakin bahwa manusia berperilaku guna mengenal dan mengapresiasi dirinya sebaik-baiknya. Teori yang termasyhur hingga saat ini yaitu teori hirarki kebutuhan. Menurutnya manusia terdorong guna mencukupi kebutuhannya. Kebutuhan-kebutuhan itu mempunyai level, dari yang paling dasar hingga level tertinggi. Dalam teori psikologinya yaitu semakin besar kebutuhan maka pencapaian yang dipunyai oleh individu semakin sungguhsungguh menggeluti sesuatu.

Perspektif ini diasosiasikan secara dekat dengan keyakinan Abraham Maslow (1954, 1971) bahwa kebutuhan dasar tertentu harus dipenuhi sebelum kebutuhan yang lebih tinggi dapat dipuaskan. Menurut hierarki kebutuhan Maslow, pemuasan kebutuhan seseorang dimulai dari yang terendah yaitu:

1. Kebutuhan Fisiologis (Physiological Needs)

Kebutuhan fisiologis terdiri dari kebutuhan pokok, yang bersifat mendasar. Selain itu juga disebut kebutuhan biologis di tempat kerja serta kebutuhan untuk menerima 
gaji, cuti, dana pensiunan, masa-masa libur, tempat kerja yang nyaman, pencahayaan yang cukup suhu ruangan yang baik. Kebutuhan tersebut biasanya paling kuat dan memaksa sehingga harus dicukupi terlebih dahulu untuk beraktifitas sehari-hari. Menandakan bahwasanya di dalam pribadi seseorang yang merasa serba kekurangan dalam kesehariannya, besar kemungkinan bahwa dorongan terkuat adalah kebutuhan fisiologis. Artinya manusia yang katakanlah melarat bisa jadi selalu terdorong akan kebutuhan tersebut.

\section{Kebutuhan akan Rasa Aman (Safety Needs)}

Sesudah kebutuhan fisiologis tercukupi, maka timbul kebutuhan akan rasa aman. Manusia yang beranggapan tidak berada dalam keamanan membutuhkan keseimbangan dan aturan yang baik serta berupaya menjauhi hal-hal yang tidak dikenal dan tidak diinginkan. Kebutuhan rasa aman menggambarkan kemauan mendapatkan keamanan akan upah-upah yang ia peroleh dan guna menjauhkan dirinya dari ancaman, kecelakaan, kebangkrutan, sakit serta marabahaya. Pengorganisasian kebutuhan semacam ini nampak pada minat akan profesi dan kepastian profesi, budaya senioritas, persatuan pekerja atau karyawan, keamanan lingkungan kerja, bonus upah, dana pensiun, investasi, dan sebagainya.

3. Kebutuhan untuk Diterima (Social Needs)

Sesudah kebutuhan fisiologikal dan rasa aman tercukupi, maka fokus individu mengarah pada kemauan akan mempunyai teman, rasa cinta dan rasa diterima. Sebagai makhluk sosial, seseorang bahagia bila mereka disukai serta berupaya mencukupi kebutuhan bersosialisasi saat di lingkungan kerja, dengan cara meringankan beban kelompok formal atau kelompok non formal, dan mereka bergotong royong bersama teman setu tim mereka di tempat kerja serta mereka berpartisipasi dalam aktifitas yang dilaksanakan oleh perusahaan dimana mereka bekerja.

4. Kebutuhan Untuk Dihargai (Self Esteem Needs)

Tingkat selanjutnya dalam teori hirarki adalah kebutuhan, Terihat kebutuhan untuk dihargai disebut juga kebutuhan "ego". Kebutuhan tersebut berkaitan dengan keinginan guna mempunyai kesan positif serta mendapat rasa diperhatikan, diakui serta penghargaan dari sesamamanusia. Pengorganisasian kebutuhan akan penghargaan memperlihatkan dorongan akan pengakuan, responsibilitas tinggi, status tinggi dan rasa akan diakui atas sumbangsih terhadap kelompok.

5. Kebutuhan Aktualisasi-Diri (Self Actualization)

Kebutuhan kebutuhan tersebut merupakan kebutuhan akan pemenuhan diri pribadi, termasuk level kebutuhan teratas. Kebutuhan tersebut diantaranya yaitu kebutuhan akan perkembangan bakat dan potensi yang ada pada diri sendiri, memaksimalkan kecakapan diri serta menjadi insan yang unggul. Kebutuhan akan pengaktualisasian diri pribadi oleh kelompok mampu dicukupi dengan diberikannya peluang untuk berkembang, tumbuh, berkreasi serta memperoleh pelatihan guna memperoleh tugas yang sesuai dan mendapat keberhasilan.

Menurut Abraham Maslow "Self-actualization, namely, to the tendency for him to become actualized. This tendency might be hrase as the desire to become more and more what one idiosyncratically is, to become everything that one is capable of becoming". Artinya bahwa kebutuhan aktualisasi diri adalah kecenderungan seseorang untuk mengerahkan semua kemampuan atau keinginannya secara terus menerus dalam menjadi pribadi yang lebih baik.

a. Implikasi Teori Abraham Maslow dalam Pendidikan Agama Islam

Adapun implikasi positif teori ini ke dalam pembelajaran PAI adalah sebagai berikut. 
1. Memenuhi kebutuhan fisiologis ialah kebutuhan makan dan minum, pakaian, tempat tinggal, termasuk kebutuhan biologis. yang merupakan kebutuhan paling dasar karena dibutuhkan semua makhluk hidup. Pemenuhan kebutuhan dasar peserta didik harus di utamakan karena kebutuhan ini sangat mendesak dan hendaknya guru memberikan kesempatan atau bantuan kepada siswa untuk memenuhinya. Dalam pembelajaran PAI sebelum memutuskan cara pembelajaran apa yang pantas diterapkan pada pembelajaran PAI, hendaknya para pendidik mengetahui terlebih dahulu keterlibatan kebutuhan-kebutuhan yang menjadi dasar motivasi dalam mencapai tujuan pembelajaran PAI mengakomondasi kebutuhan rasa aman secara fisik maupun psikis.

2. Mengakomondasi kebutuhan rasa aman secara fisik maupun psikis. Aman secara fisik, seperti terhindar dari kriminalisasi, teror, binatang buas, orang ain, tempat yang kurang aman dan sebagainya. sedangkan Aman secara psikis, seperti tidak di marah, tidak direndahkan, tidak dipindahkan tanpa keterangan, diturunkan pangkatnya dan sebagainya. Kebutuhan akan keamanan di kelas menjadi tanggung jawab guru. Tugas guru ialah menetapkan peraturan dan jaminan atas keselamatan siswa serta kenyamanan kelas.

3. Kebutuhan sosial dibutuhkan seseorang supaya ia dianggap sebagai warga komunitas sosialnya. Bagi seorang siswa agar bisa belajar dengan baik, ia harus merasa diterima dengan baik oleh teman-temannya. Terkait dengan kebutuhan sosial siswa, guruhendaknya memberikan perhatian supaya siswa mampu berinteraksi dengan baikdan mempunyai rasa saling memiliki terhadap teman-temannya serta lingkungan sekelilingnya.

4. Kebutuhan ego termasuk juga keinginan untuk mendapatkan prestasi dan memiliki wibawa. Seseorang membutuhkan sebuah kepercayaan serta tanggung jawab dari orang lain. Peserta didik perlu suasana dn lingkungan yg kondusif untuk mngaktualisasikan dirinya. Prestasi siswa sekecil apapun perlu diberikan apresiasi. Memberikan sebuah penghargaan pada peserta didik mampu memotivasi siswa untuk meningkatkan prestasinya.

5. Kebutuhan aktualisasi merupakan kebutuhan untuk menunjukkan dan membuktikan dirinya padaorang lain. Pada tahapan ini seseorang akan mengembangkan semaksimal mungkin potensi yang mereka miliki. Untuk mengaktualisasikan dirinya peserta didik perlu suasana dan lingkungan yang kondusif._ Ketika peserta didik sudah di tahap aktualisasi diri,guru hanya tinggal memberikan fasilitas yang diperlukan untuk mengembangkan dirinya secara lebih jauh. Abraham Maslow dengan teori motivasinya mengorieantasikan manusia sebagai subjek yang dapat mengembangkan potensipotensiyang dimilikinya untuk kemudiandapat mengaktualisasikan diri sebagai manusia yang utuh. Konsep ini sejalan dengan tujuan ajaran Agama Islam yang selalu mengedepankan nilai-nilai agama sebagai landasan motivasi untuk berbuat. Salah satunya menjalankan kewajiban khilafah di muka bumi.

Teori selanjutnya yaitu menurut Carl Rogers, dimana ada dua tipe belajar, yaitu kognitif (kebermaknaan) dan eksperimental (pengalaman). Guru memberikan makna (kognitif) bahwa tidak membuang sampah sembarangandapat mencegah terjadinya banjir. Jadi, guru perlu menghubungkan pengetahuam akademik ke dalam pengetahuan bermakna. Sementara experimental learning melibatkan peserta didik secara personal, berinisiatif, termasuk penilaian terhadap diri sendiri (self assessment).

Menurut Carl Rogers dalam teori belajar bebasnya, ia menyatakan bahwa tidak ada paksaan atau tekanan dalam belajar. Guru tidak bembuat rencana dalam pembelajaran untuk peserta didik, tidak memberikan kritik atau ceramah kecuali apabilasiswa menghendakinya, tidak menilai atau mengkritik pekerjaan murid kecuali apabila siswa memintanya. 
Buku yang berjudul "Freedom to Learn", memperkenalkan beberapa prinsip prinsip belajar humanistik yang sangat penting di antaranya ialah:

- Manusia itumemiliki kemampuan untuk belajar secara alami.

- Belajar yang bermakna terjadi apabila subjek matter dirasakan peserta didik mempunyai relevansi dengan maksud-maksudya sendiri.

- Belajar yang melibatkan suatu perubahan yang ada di dalam tanggapan mengenai dirinya, dianggap mengancam dan cenderung akan ditolaknya.

- Pekerjaan-pekerjaan belajar yang dapat mengancam diri adalah sangat mudah untuk dirasakan dan mudah diasimilasikan apabila ancaman dari luar tersebut semakin kecil.

- Apabila ancaman kepada diri peserta didik rendah, pengalaman bisa diperoleh dengan melakukan berbagai cara yang bermacam-macam dan terjadilah sebuah proses belajar.

- Belajar yang berarti bisa di dapatkan peserta didik dengan melakukannya.

- Belajar dapat diperlancar bilamana peserta didik dilibatkan langsung dalam proses pembelajaran dan ikut serta bertanggung jawab dalam proses belajar tersebut.

- Belajar atas inisiatif diri sendiri yang melibatkan diri peserta didik seutuhnya, baik itu perasaan maupun segi kognitif, merupakan cara yang bisamemberikan hasil yang mendalam dan lestari.

- Kepercayaan pada diri sendiri, kemerdekaan, kreatifitas akan lebih mudahuntuk dicapai apabila peserta didik dibiasakan untuk mawas diri dan mengeritik dirinya sendiri dan penilaian diri orang lain adalah cara kedua yang juga penting.

- Belajar yang sangat berperan secara sosial di dunia modern ini adalah belajar yang menyangkut proses belajar, yang terbuka dan terus menerus pada pengalaman dan penyatuannya ke dalam dirinya sendiri mengenai proses perubahan itu.

Carl Rogers menyatakan bahwa peserta didik yang belajar hendaknya tidak ditekan, melainkan dibiarkan belajar bebas, peserta didik diharapkan bisa mengambil sebuah langkah sendiri dan berani bertanggung jawab atas langkah-langkahyang diambilnya sendiri. Rogers menyatakan ada lima hal yang penting dalam proses belajar humanistic yaitu pertama, hasrat untuk belajar: keinginan untuk belajar dikarenakan adanya dorongan rasa ingin tahu manusia yang terus menerus terhadap dunia sekelilingnya. Kedua, belajar bermakna bahwa seseorang yang beraktivitas akan selalu mempertimbangkan apakah aktivitas tersebut mempunyai makna bagi dirinya. Ketiga, belajar tanpa hukuman merupakan belajar yang terlepas dari hukuman atau ancaman menghasilkan anak bebas untuk melakukan apa saja dan mengadakan percobaan hingga menemukan sendiri suatu hal yang baru. Keempat, belajar dengan daya usaha atau inisiatif sendiri: menunjukkan tingginya motivasi internal yang dimiliki. Siswa yang banyak inisiatif, akan mampu untuk memandu dirinya sendiri, menentukan pilihannya sendiri dan berusaha mempertimbangkan sendiri hal yang baikbagi dirinya. Kelima, belajar dan perubahan yaitu keadaan dunia terus berubah, karena itu peserta didik harus belajar untuk dapat menghadapi serta menyesuaikan kondisi dan situasi yang terus berubah. Belajar yang hanya mengingat fenomena atau menghafal kejadian dianggap tak cukup.

Implikasi Teori Belajar Humanistik Carl Rogers dalam Pembelajaran PAI

1. Confluent Education 
Confluent education adalah proses pendidikan yang memadukan antara pengalaman afektif dan belajar kognitif (pengetahuan) di dalam kelas. Hal ini adalah cara yang sangat bagus untuk melibatkan peserta didik secara pribadi dalam bahan pelajaran. Dalam pembelajaran ini siswa tidak hanya memperhatikan atau membaca, tetapi siswa juga dapat merasakan, menuliskan, menghayati, berdebat yang positif, dan menyampaikan pendapat mereka.

2. Cooperative Learning

Pembelajaran cooperative learning mengacu pada metode pembelajaran, yang mana peserta didik bekerja sama dengan kelompok kecil dan saling membantu dalam belajar. Menurut pernyataan Salvin, anggota-anggota kelompok bertanggung jawab atas ketuntasan tugas-tugas kelompok danmempelajari materi sendiri.

Menurut Johnson \& Johnson yang dikutip Jamil Suprihatiningrum, ada lima unsur penting dlaam belajar kooperatif, yakni sebagai berikut:

1. Saling ketergantungan secara positif

Peserta didik akan merasa dalam bahwa belajar kooperatif mereka sedang bekerja bersama untuk mencapai satu tujuan dan terkait satu sama lain. Seorang pesertadidik akan sukses apabila bagian kelompoknya juga sukses. peserta didik akan merasa bahwa dia juga bagian dari pada kelompok yang memiliki andil terhadap kesuksesan kelompoknya.

2. Interaksi tatap muka semakin meningkat

Interaksi langsung akan semakin meningkat, Belajar kooperatif akan meningkatkan interaksi peserta didik. Hal ini terjadi jika seorang peserta didik akan membantu temannya yang lain untuk sukses sebagai anggota kelompok. Saling memberikan bantuan akan berlangsung secara alamiah karena kegagalan seseorang dalam kelompok dapat memperngaruhi keberhasilan kelompok. Untuk mengatasi permasalahan ini, peserta didik yang membutuhkan bantuan akan diperoleh dari teman kelompoknya. Interaksi yang terjadi dalam pembelajaran kooperatif ialah dalam tukarmenukar ide berkenaan permasalahan yang sedang dipelajari.

3. Tanggung jawab individual

Tanggung jawab individual di dalam belajar kelompok bisa berupa tanggung jawab peserta didik dalam hal: Pertama membantu temannya yang sedang membutuhkan bantuan, kedua peserta didik tidak bisa hanya sekedar "menebeng" pada hasil kerja teman satu kelompoknya.

4. Keterampilan interpersonal dan kelompok keci

Keterampilan interpersonal dan kelompok kecil di dalam belajar kooperatif, selain diminta untuk belajar materi yang akan diberikan, peserta didik juga diminta untuk belajar bagaimana agar peserta didik mampu berinteraksi dengan peserta didik lain dalam kelompoknya. Bagaimana peserta didik bersikap selaku anggota kelompok dan menyampaikan gagasan mereka dalam kelompok akan menuntut keterampilan khusus.

5. Proses kelompok

Proses kelompok Belajar kooperatif tidak dapat berlangsung tanpa adanya proses kelompok. Proses kelompok terjadi apabila anggota kelompok mendiskusikan dan bekerja sama bagaimana mereka akan menggapai tujuan dengan baik dan membuat hubungan kerja kelompok yang baik.

\section{V.Simpulan}

Berdasarkan hasil penelitian, maka dapat disimpulkan bahwa Pembelajaran dalam pendekatan humanistik dipahami sebagai pembelajaran yang mengarah pada proses memanusiakan manusia banyak sekali manfaatnya di antaranya membentuk kepribadian, hati nurani, perubahan sikap yang baik. Manfaat selanjutnya yaitu 
membiasakan melakukan hal-hal yang bersifat demokratis, partisipatif dialogis dan humanis. Menumbuhkan suasana pembelajaran yang saling menghargai, kebebasan berpendapat, kebebasan mengungkapkan ide/gagasan. Peserta didik juga merasa senang, bergairah, berinsiatif dalam belajar. Manfaat terakhir yaitu merubah pola pikir, perilaku sikap yang kurang baik misalnya bekerja atas kemauan sendiri, tidak jujur, dan lain-lain.

\section{Referensi}

Arbayah, Model Pembelajaran Humanistik, Vol 13. No. 2, Desember 2013.

Armaja Prawira, Purwa, Psikologi Pendidikan dalam Perspektif Baru, Yogyakarta: ArRuzz Media, 2013.

Feist, Jess, Teori Kepribadian, Jakarta: Penerbit Salemba Humanika, 2009.

Iskandar, Implementasi Teori Hirarki Kebutuhan Abraham Maslow Terhadap Peningkatan Kinerja Pustakawan, Vol. 4 No. 1, Januari -Juni2016.

Ismail, Fajri, Evaluasi Pendidikan, Palembang: Tunas Gemilang Press, 2014

Komara, Endang, Belajar dan Pembelajaran Interaktif, Bandung: PT Refrika Aditama, 2014.

Maslow, Abraham H, Motivation And Personality, Harper \& Row: 1970.

Nova Irawan, Eka, "Buku Pintar Pemikiran Tokoh-Tokoh Psikologi dariKlasik Sampai Modern," Yogyakarta: IRCiSoD, 2005.

Rumini, Jamil, Psikologi Pendidikan, Yogyakarta: UPP IKIP Yogyakarta, 1993.

S. Freidman, Howard, Kepribadian Teori Klasik dan Riset Modern, Jakarta: Erlangga, 2008.

Sanusi, Uci, Pembelajaran dengan Pendekatan Humanistik, vol.11 No.2, 2013.

Sardiman, Interaksi Dan Motivasi Belajar Mengajar, Jakarta: PT Raja Grafindo, 2005.

Siregar, Eveline, Teori Belajar dan Pembelajaran, Bogor: Ghalia Indonesia, 2011.

Soemanto, Wasty, Psikologi Pendidikan, Jakarta: Bina Aksara, 1987.

Suprihatin, Pendekatan Humanistik dalam Pengembangan Kurikulum Pendidikan Agama Islam, Vol. 3, No. 1, Januari -Juni 2017.

Suprihatiningrum, Jamil, Strategi Pembelajaran: Teori dan Aplikasi, Yogyakarta: ArMedia, 2013.

W. Santrock, John, Psikologi Pendidikan, Jakarta: Salemba Humanika, 2009.

Zulfikar, Konseling Humanistik: Sebuah Tinjauan Filosofi, Vol. 3 No. 1 Januari-Juni 2017. 